\author{
P.A. Esenbekova ${ }^{1}$, T.O. Altynbek ${ }^{2 *}$, M.B. Zhaksybayev ${ }^{2}$ \\ ${ }^{1}$ Institute of Zoology, Almaty, Kazakhstan; \\ ${ }^{2}$ Abai Kazakh National Pedagogical University, Almaty, Kazkahstan; \\ *Corresponding author: tolganay.altynbek@mail.ru
}

\title{
Materials for the aquatic hemiptera (Heteroptera) fauna of the Charyn State National Natural Park
}

\begin{abstract}
As a result of research in 2019, 21 species out of 7 families of Hemoptera were identified in the Charyn State National Natural Park. From these species composition, 14 species are zoophages; the remaining 7 species are zoophytophages. Identified all species have a wide selection of hunting objects, feed on aquatic invertebrates, including regulating the numbers of blood-sucking mosquito larvae (Culicidae). The main purpose of the research is to identify the species composition of the aquatic hemiptera Charyn State National Natural Park. Here, a systematic special study of the fauna of the aquatic hemiptera was not carried out before. Only 2 articles on half-winged animals have been published. Aquatic Hemiptera insects by species diversity and environmental features are one of the groups most suitable for its use in various environmental studies; they are well adapted to various environmental conditions.
\end{abstract}

Keywords: fauna, Heteroptera, Charyn State National Natural Park, family, larva.

\section{Introduction}

Hemiptera is a vast group of insects with a moderately flattened body, piercing-sucking mouth type of oral organs belonging to insects with incomplete transformation, in which the intermediate stage between egg and imago is called nymph.

Aquatic Hemiptera are insects, all their life and development of which takes place in water bodies. They are divided into 2 ecological groups: Gerromorpha - water strides (5 families) living on the surface of water or wet banks of water bodies, and Nepomorpha - water bugs ( 8 families) living in the thickness of water or on the bottom.

Practically all water bedbugs are predators, only species of Corixidae family can feed on both animal foods and algae and detritus. Many species kill larvae and mummuies of blood-sucking insects living in water. Some species harm fish farming by attacking caviar and midge. Water bugs themselves and their numerous larvae are the object of nutrition for aquatic and semi-aquatic animals [1,2].

\section{Materials and methodology}

The material of this work is the collections of authors in 2019 in the territory of Charyn State National Natural Park. Various techniques [3-7] have been used to collect Hemiptera: fishing of entomological water dip nets, night fishing, etc. The fauna of water Hemiptera of Charyn State National Natural Park is not fully reflected in this work, because it hasn't been studied in depth yet. The following are species found in the studied territories. For each of species are given the date of collection, short information on distribution, biology and ecology.

\section{Results and discussion}

\section{Family Nepidae - Water scorpions}

Nepa cinerea Linnaeus, 1758. Charyn State National Natural Park, Sharyn River. 14.07.2019, $3 \propto$, 5 $\jmath_{\text {, }}$ 24.08.2019, 4ㅇ, 3 3 . Standing and slowly flowing large and small bodies of water (live in the thickness of water, does not swim well, so walks on the bottom or water plants; Zoophage (adults andlarvae feed on the larvae of dragonflies, blindness and beetles); monovoltine; Winters imago, but can also winter larvae of $\mathrm{V}$ age [8].

Ranatra linearis (Linnaeus, 1758). Charyn State National Natural Park, cordon No. 4. 10.07.2019, 1 , $2 \hat{\jmath}$ found in Sharyn river, 04.08.2019, $+4 \phi, 2 \hat{\jmath}+4$ larvae III-I V age. Standing and slowly flowing large and small bodies of water; Zoophage (destroys fish dip nets, dragonfly larvae and beetles); Monovoltine [9, 10] or bivoltine [11]; Winters imago. 
Family Corixidae - Boat Bugs

Micronecta pusilla (Horvath, 1895). Charyn State National Natural Park, bottomland of the Sharyn River, 23.07.2019, 2 q, 4 $\lesssim$. Standing and slowly flowing large and small bodies of water; zoophytophage; monovoltine; The larvae winter.

Cymatia coleoptrata (Fabricius, 1777). Charyn State National Natural Park, bottomland of the Sharyn River, 05.08.2019, 3 q, 2 $\lesssim$. Standing and slowly flowing large and small bodies of water; zoophytophage; monovoltine; Winters imago.

Hesperocorixa linnaei (Fieber, 1848). Charyn State National Natural Park, inundated standing reservoir of the Sharyn River, 10.07.2019, 5 q, 6 ऽ. In floodwater bodies with standing water and well-developed vegetation; zoophytophage; monovoltine; Winters imago in the water basin [12].

Hesperocorixa sahlbergi (Fieber, 1848). Charyn State National Natural Park, a water body with standing water near cordon No. 4. 04.08.2019, 4q, $3 \hat{\jmath}$. Various standing and slowly flowing large and small bodies of water; zoophytophage; monovoltine; Winters imago.

Paracorixa kiritshenkoi (Lundbland, 1933). Charyn State National Natural Park, inundated reservoir of the Sharyn River, 15.07.2019, 4, 3 o. In the steppe zone and desert zones in floodwater bodies of rivers and lakes; zoophytophage; monovoltine; Winters imago. Flying into the light.

Sigara nigrolineata nigrolineata (Fieber, 1848). Charyn State National Natural Park, inundated standing reservoir of the Sharyn River, 06.07.2019, $9 \stackrel{\circ}{,} 3 \hat{\sigma}$. In a variety of small standing and weakly flowing water bodies; zoophytophage; polivoltine; Winters imago [5].

Sigara limitata limitata (Fieber, 1848). Charyn State National Natural Park, flood plain of the Sharyn River, 06.07.2019, 3 + $3 \hat{\jmath}$. It lives in standing or weakly flowing well-warmed water bodies with rich vegetation; zoophytophage; monovoltine; Winters imago.

Sigara striata (Linnaeus, 1758). Charyn State National Natural Park, bottomland of the Sharyn River, 14.07.2019, 3 q, 2 $\lesssim$. Euritope, in all sorts of standing, weakly flowing, floodwaters, but avoids heavily polluted; Zoophytophage (plant and animal food, exterminates mosquito larvae); polivoltine; Winters imago (in water bodies). Flies well and arrives at night to light [5].

Sigara distincta (Fieber, 1848). Charyn State National Natural Park, bottomland of the Sharyn River, 08.07.2019, 4 ㅇ, $3 \hat{\jmath}$. In a variety of standing and floodwater bodies, in silted areas with water vegetation; zoophytophage; Polyvoltine [12]; Winter imago.

Sigara falleni (Fieber, 1848). Charyn State National Natural Park, bottomland of the Sharyn River, 10.07.2019, 5 9, 6 ô. In weakly flowing, various flood and standing water bodies, river plants, lakes, including moderately contaminated ones; zoophytophage; bivoltinny; Winters imago. Lives and winters in a body of water. There is information about destruction by these bedbugs of larvae of a white fat plate in Rostov region [13].

Sigara longipalis (J. Sahlberg, 1878). Charyn State National Natural Park, bottomland of the Sharyn River, 24.08.2019, 4 ㅇ, 3 ふै. It lives in floodwater standing bodies: necton; zoophytophage; Polyvoltine [14]; Winters imago.

FamilyNaucoridae - Plautus

Ilyocoris cimicoides cimicoides (Linnaeus, 1758). Charyn State National Natural Park, bottomland of

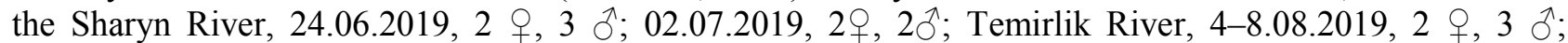

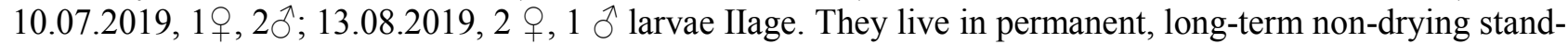
ing and slowly flowing water bodies with developed vegetation; Zoophage (prefers to eat and attack small, weakly-chitinized inhabitants of water bodies: dragonfly larvae, leeches, side-swimmers, as well as larvae of blood-sucking mosquitoes of Aedes and Culex genera); monovoltine; Imago is wintered on land, buried in soil in upper layer of soil. Winter of water creepers on land is showed in other publications $[5,8,15]$.

\section{FamilyNotonectidae - Back swimmers}

Notonecta glauca glauca Linnaeus, 1758. Charyn State National Natural Park, bottomland of the Sharyn

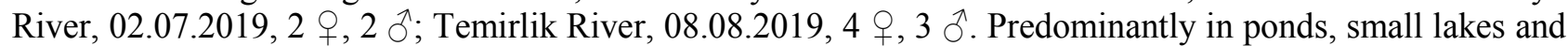
various floodwater bodies with standing or weakly flowing water. Zoophage, larvae of initial ages feed on small larvae of aquatic beetles, mosquitoes and fallen insects into the water. Monovoltine; Winter imago.

\section{Family Pleidae - Pleids}

Plea minutissima minutissima Leach, 1817. Charyn State National Natural Park, inundated standing reservoir of the Sharyn River, 24.08.2019, 3 ㅇ, $3 \hat{\delta}$. Standing and slowly flowing large and small bodies of 
water with abundant of vegetation; Zoophage (both imago and larvae feed on larvae of various hydrobionts); monovoltine; Winters imago [8].

\section{Hydrometridae family - Stick-shaped water strides}

Hydrometra stagnorum (Linnaeus, 1758). Charyn State National Natural Park, bottomland of the Sharyn River, 02.07.2019, 2 ㅇ, 2 đ; Temirlik River, 08.08.2019, 4 q, 3 o. On floating leaves of aquatic plants or along banks standing or weakly flowing water bodies, on wet soil and mosses; Zoophage (small arthropods); Possibly monovoltine; Winters imago on the shore [8].

\section{Family Gerridae - Water strides}

Gerris argentatus Schummel, 1832. Charyn State National Natural Park, bottomland of the Sharyn Riv-

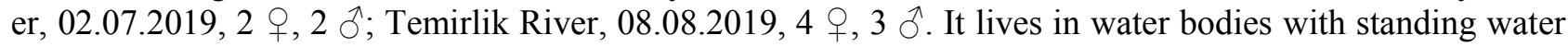
and with a partially overgrown mirror, and quickly slides on the surface of the water. Zoophage; bivoltine; Winter imago.

Gerris lacustris (Linnaeus, 1758). Charyn State National Natural Park, bottomland of the Sharyn River,

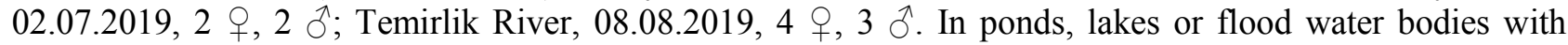
standing water and developed vegetation, on the surface of water of different water bodies; Zoophage (small aqueous arthropods); polyvoltine; Imago is wintered [8].

Gerris costae (Herrich-Schaffer, 1850) in the territory of Kazakhstan the species is represented by the subspecies Gerris costae fieberi Stichel, 1938. Charyn State National Natural Park, bottomland of the Sharyn

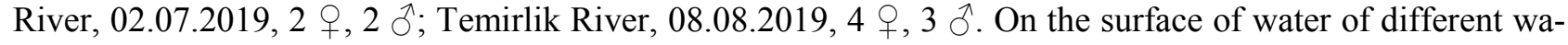
ter bodies, everywhere in puddles; zoophage; Probably bivoltine; Winters imago.

Limnoporus rufoscutellatus (Latreille, 1807). Charyn State National Natural Park, bottomland of the

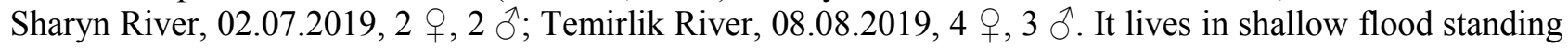
water bodies with a partially overgrown water mirror, in marshy overgrown ponds, and in large lakes, sometimes along river banks, among vegetation, in shaded areas among the stems of aquatic plants, avoids an open water mirror; Ecologically plastic, very conventional species; Zoophage (gnus number regulator); polyvoltine; Imago is wintered [8] (Table 1).

T a b l e 1

Taxonomic composition of AquaticHemiptera of Charyn State National Natural Park

\begin{tabular}{|c|c|c|c|c|}
\hline Family & Species & Amount & Trophic connection & Winter stage \\
\hline Nepidae & $\begin{array}{l}\text { Nepa cinerea Linnaeus, } 1758 \\
\text { Ranatra linearis (Linnaeus, 1758) }\end{array}$ & 2 & $\begin{array}{l}\text { Zoophage } \\
\text { Zoophage }\end{array}$ & Imago, Larvae \\
\hline Corixidae & $\begin{array}{l}\text { Micronecta pusilla (Horvath, 1895) } \\
\text { Cymatia coleoptrata (Fabricius, 1777) } \\
\text { Hesperocorixa linnaei (Fieber, 1848) } \\
\text { Hesperocorixa sahlbergi (Fieber, 1848) } \\
\text { Paracorixa kiritshenkoi (Lundbland, 1933) } \\
\text { Sigara nigrolineata nigrolineata (Fieb., 1848) } \\
\text { Sigara limitata limitata (Fieber, 1848) } \\
\text { Sigara striata (Linnaeus, 1758) } \\
\text { Sigara distincta (Fieber, 1848) } \\
\text { Sigara falleni (Fieber, 1848) } \\
\text { Sigara longipalis (J.Sahlberg, 1878) }\end{array}$ & 11 & $\begin{array}{l}\text { Zoophytophage } \\
\text { Zoophytophage } \\
\text { Zoophytophage } \\
\text { Zoophytophage } \\
\text { Zoophytophage } \\
\text { Zoophytophage } \\
\text { Zoophytophage } \\
\text { Zoophytophage } \\
\text { Zoophytophage } \\
\text { Zoophytophage } \\
\text { Zoophytophage }\end{array}$ & $\begin{array}{l}\text { Imago } \\
\text { Larvae } \\
\text { Imago } \\
\text { Imago } \\
\text { Imago } \\
\text { Imago } \\
\text { Imago } \\
\text { Imago } \\
\text { Imago } \\
\text { Imago } \\
\text { Imago }\end{array}$ \\
\hline Naucoridae & Ilyocoris cimicoides cimicoides (L., 1758) & 1 & Zoophage & Imago \\
\hline Notonectidae & Notonecta glauca glauca Linnaeus, 1758 & 1 & Zoophage & Imago \\
\hline Pleidae & Plea minutissima minutissima Leach, 1817 & 1 & Zoophage & Imago \\
\hline Hydrometridae & Hydrometra stagnorum (L., 1758) & 1 & Zoophage & Imago \\
\hline Gerridae & $\begin{array}{l}\text { Gerris argentatus Schummel, 1832 } \\
\text { Gerris lacustris (Linnaeus, 1758) } \\
\text { Gerris costae costae (Herrich-Schaffer, 1850) } \\
\text { Limnoporusrufoscutellatus(Latreille, 1807) }\end{array}$ & 4 & $\begin{array}{l}\text { Zoophage } \\
\text { Zoophage } \\
\text { Zoophage } \\
\text { Zoophage }\end{array}$ & $\begin{array}{l}\text { Imago } \\
\text { Imago } \\
\text { Imago } \\
\text { Imago }\end{array}$ \\
\hline Total: & & 21 & & \\
\hline
\end{tabular}


The nutrition of the Hemiptera is extremely diverse. By food connections, predators (zoophages) and mixed-food species (zoophytophages), which consume both plant and animal food, are distinguished among aquatic bedbugs. According to Table 1, zoophages are $45 \%$ and zoophytophages $-55 \%$.

Bedbugs are characterized by wintering at different stages of development. In most species, winter diapause occurs at the imago stage, but few species winter at the larval stage. Usually the first to appear are species wintering at the imago stage (Table 1), such species majority $(90 \%)$ and at the larval stage (10\%).

Hemiptera of Charyn State National Natural Parkis characterized by 3 known types of voltinism: monovoltinism (one generation per year) - 11 species $(52 \%)$, bivoltinism (two generations per year) 4 species $(19 \%)$, polyvintinism (more than two generations per year) -6 species $(29 \%)$.

\section{Conclusions}

As a result of studies carried out on the territory of the Charyn State National Natural Park, 21 species of Aquatic Hemiptera out of 7 families were identified. The largest in volume were collection of representatives of family Corixidae is 11 species, Gerridae is 4 species, with only 1-2 species known in the rest of the families. According to food connections among water bugs of Charyn State National Natural Park zoophages make up $-45 \%$, zoophytophages $-55 \%$. Bedbugs are characterized by wintering at different stages of development, here wintering at the stage of imago $90 \%$ and at the stage of larvae $10 \%$. Hemiptera Charyn State National Natural Park is characterized by 3 types of voltinism: monovoltinism - 52\%, bivoltinism $-19 \%$, polyvoltinism $-29 \%$.

\section{References}

1 Есенбекова П.А. Полужесткокрылые (Heteroptera) Чарынского природного парка / П.А. Есенбекова // Науч. журн. «Терpa». - 2009. - № 1(6). - С. 79-82.

2 Есенбекова П.А. Су қандалалары (Heteroptera) - Шарын ұлттық табиғи паркіндегі қансорғыш қосқанаттылардың биореттеушілері / П.А. Есенбекова // Современное состояние биоразнообразия Чарынского государственного национального природного парка и прилегающих территорий: материалы науч. конф. - Алматы, 2014. - С. $43-45$.

3 Кириченко А.Н. Настоящие полужесткокрылые Европейской части СССР (Hemiptera) / А.Н. Кириченко // Определитель и библиография. - М.-Л.: Изд-во АН СССР, 1951. - 423 с.

4 Кириченко А.Н. Методы сбора настоящих полужесткокрылых и изучения местных фаун / А.Н. Кириченко. - М.-Л.: Изд-во АН СССР, 1957. - 124 с.

5 Кержнер И.М. Отряд Heteroptera (Hemiptera) полужесткокрылые / И.М. Кержнер, Т.Л. Ячевский // Определитель насекомых Европейской части СССР. - М.-Л.: Наука, 1964. - Т. 1. - С. 655-843.

6 Винокуров Н.Н. Насекомые полужесткокрылые (Heteroptera) Якутии / Н.Н. Винокуров. — Л.: Наука, 1979. — 232 с.

7 Канюкова Е.В. Водные полужесткокрылые насекомые (Heteroptera: Nepomorpha, Gerromorpha) фауны России и сопредельных стран / Е.В. Канюкова. - Владивосток: Дальнаука, 2006. - 296 с.

8 Фасулати К.К. Полевое изучение наземных беспозвоночных / К.К. Фасулати. — М.: Высш. шк., 1971. — 424 с.

9 Papacek M. Life cycles of univoltine water bugs (Heteroptera, Nepomorpha) in Czechoslovakia / M. Papacek // PraceSlov. Ent. Spol. SAV. - 1989. - Vol. 8. - P. 45-52.

10 Dolling W.R. The Hemiptera / W.R. Dolling. — Oxford: Oxford University Press (Natural History Museum Publication), 1991. - 274 p.

11 Дубицкий А.М. Биологический метод борьбы с гнусом в СССР / А.М Дубицкий. — Алма-Ата, 1978. — 267 с.

12 Jansson A. Identification of larval Corixidae (Heteroptera) of northern Europe / A. Jansson // Annals zool. fenn. — 1969. Bd. 6. - S. 289-312.

13 Сокольская Н.П. О биологии клопов-гребляков, вредящих рыбоводству в Ростовской области / Н.П. Сокольская, Л.Д. Житенева // Зоол. журн. - 1973. - Т. 52, Вып. 9. — С. 1330-1334.

14 Jansson A. The Corixidae (Heteroptera) of Europe and some adjacent regions / Jansson A. // Acta Entomologica Fennica. 1986. - Vol. 47. — $93 \mathrm{p}$.

15 Винокуров Н.Н. Полужесткокрылые (Heteroptera) Сибири / Н.Н. Винокуров, Е.В. Канюкова. - Новосибирск: Наука, 1995. - 235 c. 


\title{
П.А. Есенбекова, Т.О. Алтынбек, М.Б. Жақсыбаев Шарын мемлекеттік ұлттық табиғи паркіндегі
су жартылайқаттықанаттылар (Heteroptera) фаунасы
}

2019 жылы Шарын мемлекеттік ұлттық табиғи паркінде (МҰТП) жүргізілген зерттеулер нәтижесінде жартылайқаттықанаттылардың 7 тұқымдасқа кіретін 21 түрі анықталды. Олардың 14 түрі зоофагтар, қалған 7 түрі - зоофитофагтар. Анықталған барлық түрлерде аң аулау нысандары кең, су омыртқасыздарымен қоректенеді, соның ішінде қан соратын масалардың личинкаларын (Culicidae) реттейді. Зерттеудің негізгі мақсаты - Шарын мемлекеттік ұлттық табиғи паркіндегі су жартылайқаттықанаттылардың түрлік құрамын анықтау. Мұнда бұрын су жартылайқаттықанаттылар жануарлар дүниесіне жүйелі түрде арнайы зерттеу жүргізілген жоқ. Осыған дейін су жартылайқаттықанаттылар туралы тек 2 мақала жарияланды. Су жартылайқаттықанаттылар түрлерінің көп түрлілігі мен қоршаған ортаның ерекшеліктері бойынша әр түрлі экологиялық зерттеулерде қолдануға қолайлы топтардың бірі болып табылады және олар әр түрлі экологиялық жағдайларға жақсы бейімделген.

Кілт сөздер: фауна, жартылайқаттықанаттылар, Шарын МҰТП, тұқымдас, личинка.

\author{
П.А. Есенбекова, Т.О. Алтынбек, М.Б. Жақсыбаев
}

\section{Материалы к фауне водных полужесткокрылых (Heteroptera) Чарынского государственного национального природного парка}

\begin{abstract}
В результате исследований в 2019 г. в Чарынском государственном национальном природном парке (ГНПП) выявлен 21 вид из 7 семейств полужесткокрылых. Из них 14 видов зоофаги, остальные 7 зоофитофаги. Все виды имеют широкий выбор охотничьих объектов, питаются водными беспозвоночными, в том числе регулируют численность личинок кровососущих комаров (Culicidae). Основная цель исследования - выявить видовой состав водных полужесткокрылых Чарынского государственного национального природного парка. Раньше планомерного специального изучения фауны водных полужесткокрылых не проводилось. Опубликовано всего две статьи по полужесткокрылым. Полужесткокрылые насекомые по видовому разнообразию и экологическим особенностям - одна из групп, наиболее пригодных для ее использования в различных экологических исследованиях, они хорошо приспособлены к различным условиям среды.
\end{abstract}

Ключевые слова: фауна, полужесткокрылые, Чарынский ГНПП, семейство, личинка.

\section{References}

1 Esenbekova, P.A. (2009). Poluzhestkokrylye (Heteroptera) Charynskoho prirodnoho parka [Heteroptera of the Charyn Natural Park]. Nauchnyi zhurnal «Terra» - Scientific journal «Terra», 1(6), 79-82 [in Russian].

2 Esenbekova, P.A. (2014). Su kandalalary (Heteroptera) - Sharyn ulttyq tabigi parkindegi qansorgysh qosqanattylardyn bioretteushileri [Aquaticheteroptera (Heteroptera) - Bioremeditors of bloodshed in Charyn National Park]. Proceedings from The current state of biodiversity of the Charyn State National Natural Park: Nauchnaia konferentsiia - Scientific conference. (p. 43-45). Almaty [in Kazakh].

3 Kirichenko, A.N. (1951). Nastoiashchie poluzhestkokrylye Evropeiskoi chasti SSSR (Hemiptera). Opredelitel i bibliohrafiia [Real half-winged European part of the USSR (Hemiptera). Determinant and Biography]. Moscow: Publ. of Acad. of Sci. of the USSR [in Russian].

4 Kirichenko, A.N. (1957). Metody sbora nastoiashchikh poluzhestkokrylykh i izucheniia mestnykh faun [Methods for collecting true half-winged animals and studying local faunas]. Moscow; Leningrad: Publ. of Acad. of Sci. of the USSR [in Russian].

5 Kerzhner, I.M., \& Yachevsky, T.L. (1964). Otriad Heteroptera (Hemiptera) poluzhestkokrylye [Order Heteroptera (Hemiptera) half-winged]. Moscow: Nauka [in Russian].

6 Vinokurov, N.N. (1979). Nasekomye poluzhestkokrylye (Heteroptera) Jakutii [Hemisphere insects (Heteroptera) of Yakutia]. Leningrad: Nauka [in Russian].

7 Kanyukova, E.V. (2006). Vodnye poluzhestkokrylye nasekomye (Heteroptera: Nepomorpha, Gerromorpha) fauny Rossii $i$ sopredelnykh stran [Aquatic semi-winged insects (Heteroptera: Nepomorpha, Gerromorpha) of the fauna of Russia and neighboring countries]. Vladivostok: Dalnauka [in Russian].

8 Fasulati, K.K. (1971). Polevoe izuchenie nazemnykh bespozvonochnykh [Field study of terrestrial invertebrates] Moscow: Vysshaia shkola [in Russian].

9 Papacek, M. (1989). Life cycles of univoltine water bugs (Heteroptera, Nepomorpha) in Czechoslovakia. Prace Slov. Ent. Spol. SAV (Bratislava), 8, 45-52.

10 Dolling, W.R. (1991). The Hemiptera. Oxford: Oxford University Press (Natural History Museum Publication). 
11 Dubitsky, A.M. (1978). Biolohicheskii metod borby s hnusom v SSSR [The biological method of fighting the vile in the USSR]. Alma-Ata [in Russian].

12 Jansson, A. (1969). Identification of larval Corixidae (Heteroptera) of northern Europe. Annals zool. fenn., 6, $289-312$.

13 Sokolskaya, N.P. \& Zhiteneva, L.D. (1973). O biolohii klopov-hrebliakov, vrediashchikh rybovodstvu v Rostovskoi oblasti [On the biology of rowing bugs harmful to fish farming in the Rostov region]. Zoolohicheskii zhurnal - Zoological Journal, 52, 9 , 1330-1334 [in Russian].

14 Jansson, A. (1986). The Corixidae (Heteroptera) of Europe and some adjacent regions. Acta Entomologica Fennica, 47, 93.

15 Vinokurov, N.N., \& Kanyukova, E.V. (1995). Poluzhestkokrylye (Heteroptera) Sibiri [Heteroptera of Siberia]. Novosibirsk: Nauka [in Russian]. 